Panjiantariksa Yusuf, DoewesMuchsin, Utomo Tri Aprilijanto. Contribution of biomotor and psychomotor factors that determine Pencak Silat Front Kick ability. Pedagogy and Psychology of Sport. 2020;6(3):83-90. elSSN 2450-6605. DOI http://dx.doi.org/10.12775/PPS.2020.06.03.006

https://apcz.umk.pl/czasopisma/index.php/PPS/article/view/PPS.2020.06.03.006

https://zenodo.org/record/4057900

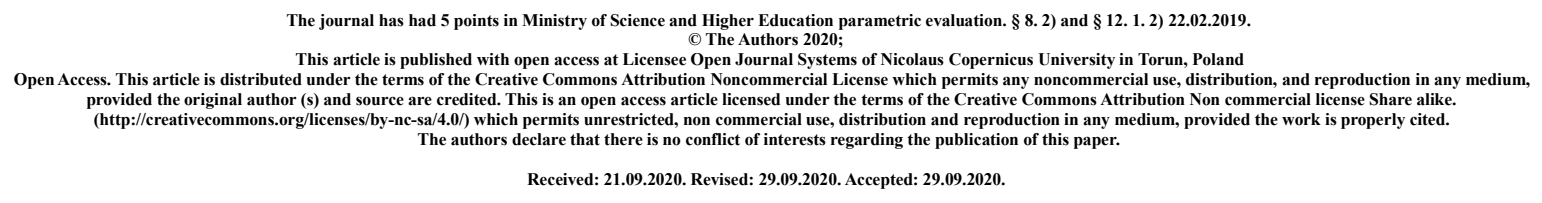

\title{
CONTRIBUTION OF BIOMOTOR AND PSYCHOMOTOR FACTORS THAT DETERMINE PENCAK SILAT FRONT KICK ABILITY
}

\author{
Yusuf Panjiantariksa ${ }^{1}$, Muchsin Doewes ${ }^{2}$, Tri Aprilijanto Utomo ${ }^{3}$ \\ Email: yusufantariksa.akademi@gmail.com¹, mdoewes2000@yahoo.com², aprili_janto@yahoo.com³
}

ORCID id: 0000-0001-7893-4784 ${ }^{1}, 0000-0001-5820-4119^{2}, 0000-0003-4043-9766^{3}$

${ }^{123}$ Postgraduate in Sports Science, Sebelas Maret University

Street Ir. Sutami Number 36 Surakarta City, Central Java, Indonesia

\begin{abstract}
This study aims to determine the contribution of biomotor and psychomotor factors that determine pencak silat front kick ability. The study uses quantitative methods and confirmatory factor analysis design. This type of research used in this research is correlational research with confirmatory factor analysis design that confirms the relationship of indicator variables with latent variables that determine the ability of the front kick pencak silat. Data collection is processed and analyzed using a computer-based application Statistics SPSS (Product Statistics and Service Solutions) Version 23 and using the Kaiser-Meyer-Olkin test and Bartlett Test. The sample is a part or representative being studied. As a sample it is better to have the same characteristics as a population so that you can draw a picture of the population. The population and sample in this study were all students fostering the achievement of Pencak Silat UKM PSHT Sebelas Maret University with a total of 25 students. The sampling technique used was purposive sampling.The technique in collecting data uses tests and measurements. The results of the study are as follows: analysis of biomotor and psychomotor factors that determine the ability of the pencak silat front kick above, the biomotor and psychomotor factors that determine the ability of the front kick of pencak silat (H0 accepted) or those that have a factor component value of $\geq 0.5$ are: Biomotor and psychomotor factors that contribute to determining the ability of pencak silat front kicks 1 . Power of leg muscles with a factor component value of 0.922 . Flexibility with a factor component value of 0.433 . Power the abdominal muscles with a factor component value of 0.534 . The balance with the factor component value is 0.915 . Agility with a factor component value of 0.24 The results of the statistical analysis of biomotor and psychomotor factors that contribute to determining the ability of the front kick of pencak silat are leg muscle power (0.92), balance (0.91), abdominal muscle power (0.53), flexibility (0.42), and agility (0.24).
\end{abstract}

Key words: Pencak Silat, Biomotor, Psychomotor, Front Kick 


\section{INTRODUCTION}

Sports is a series of regular and planned physical exercises that are done by conscious people to improve their functional skills (1). Any sport, be it an individual, team or game sport is very much determined by the factors that determine the success of the sport both intrinsic (from the body) and extrinsic (from the surrounding environment). These factors include: technical factors, tactics, mental, biomotor (physical), psychomotor, anthropometry, motivation, nutrition, genetics, and others (2).

Pencak silat is a martial art inherited from ancestors as the culture of the Indonesian people, therefore it needs to be preserved, nurtured and developed (3). Pencak silat is a martial arts method that was created to defend against dangers that can threaten safety and survival (4). In the Indonesian dictionary, pencak silat is defined as expertise in defending themselves with the skill of parrying, attacking and defending themselves with or without weapons (5). Kick technique is one of the important attack techniques in pencak silat (6).

Pencak silat is a martial attack movement in the form of dance and rhythmic customary rules that can be performed in public, while Silat is the essence of pencak, the knowledge of fighting or defending oneself. death which cannot be performed in public (7). Along with the development of the times, pencak silat is not only a tool for self-defense but that Pencak Silat is used as a sporting tool and advice to devote love to the aspects of beauty, and a means of mental and spiritual education (8).

Pencak silat has a game (expertise) in defending themselves with the skill of parrying, attacking and defending themselves, both with weapons or without weapons (9). The basic motion of pencak silat is a movement, planned, directed, coordinated and controlled which has four aspects as a single unit, namely mental spiritual aspects, martial aspects, sports aspects, and cultural arts aspects (10). The basic movements include (11):

1. Horses: This technique is used to support the attitudes of pencak silat pairs, the horses are also used as basic pencak silat exercises to strengthen leg muscles.

2. Attitude Attitude: Tactic attitude to deal with opponents who have a pattern of attacking or welcoming, when viewed from a martial system the attitude of tides means that conditions are optimal for combat.

3. Step Pattern: Is a technique of footwork in moving and changing positions to approach or away from the opponent in order to get a better or favorable position that is combined and coordinated with posture and hand posture.

4. Defend: Efforts to thwart attacks with rebuttal or evasion. Defense is divided into two namely rebuttal and evasion.

5. Hand strikes Among them are front punch, side punch, cump blow, slash, stab etc.

6. Sweep and Grip, Sweep consists of upright sweep. Sweep fell, Sabetan, Beset. Snoring is an attack that uses the knee / knee as a means of attack, with the target of the genitals, chest, and back of the waist, including among the front snuff, front side snoring, outside side snoring.

7. Cutouts: The technique of dropping an opponent is done by pinning both legs on the target neck, waist or legs so that the opponent falls.

8. Catching: A technique of catching the opponent's hand, foot or limb with one or two hands and will proceed with other movements.

9. Leg attacks Among them: Straight kicks, Side kicks, Sickle kicks, Back kicks, Prick kicks, Kepret kicks, Footage kicks, Hard kicks, Spurs kicks.

A straight kick (front) is a kick that uses the tip of the foot with a straight leg. This kick is pointing forward at the target by straightening the leg to toe. The part of the foot that is hit when kicking is the base of the inside of the fingers. Position the body facing the target (12). 
Biomotor is the ability of human motion that is influenced by the condition of internal organ systems (13). The internal organ system in question namely: the neuromuscular system, respiration, blood circulation, energy systems, bones, and joints. Biomotor component is influenced by energy fitness and muscle fitness. Energy fitness includes aerobic and anaerobic capacity. While muscle fitness (muscular fitness) include: strength, endurance, speed, explosive power or power, flexibility (14).

The psychomotor domain refers to the behavior of movement or body control (15). Psychomotor activities are oriented towards body movements and emphasize physical responses that are visible or can easily be seen. The term psychomotor domain can also be called the motor domain. This domain includes various kinds of gesture behavior.

Classification is an operational definition of the term psychomotor, namely all human movements that are conscious and observable (16). Psychomotor domain into 6 levels and each level has sub-levels (17), namely as follows:

1. Reflex movement.

2. Fundamental basic movements.

3. Perceptual ability.

4. Physical ability.

5. Movement skills.

6. Non-discursive communication

Biomotor and psychomotor play a very important role in maintaining or increasing the degree of physical fitness (physical fitness). The degree of a person's physical fitness greatly determines physical skills in carrying out daily tasks. The higher the degree of physical fitness, the higher the physical work skills. In other words, the results of his work will be more productive if his physical fitness increases. Biomotor and psychomotor training are the main programs in training athletes to excel in sports (18).

Athletes who have good biomotor and psychomotor levels will avoid injury. Physical conditioning program needs to be planned systematically (19). The goal is to improve biomotor and psychomotor. The process of physical conditioning exercises that are carried out carefully and repeatedly will improve biomotor and psychomotor. This causes a person to become increasingly skilled, strong and efficient in carrying out his movements. An athlete who follows an intensive physical conditioning training program for 6-8 weeks prior to the season will have much better strength, flexibility and endurance during the season. The development of the best physical condition also helps an athlete to be able to follow the next training in an effort to achieve the highest achievement.

The factors that support the achievement of pencak silat achievements need to be trained and improved more intensively and optimally (20). One of the factors that must be trained to achieve skills in playing pencak silat is by mastering the techniques and tactics in pencak silat (21). One of them is mastery of kick technique and tactics (22). Therefore, the researcher was interested in using a sample of UKM PSHT UNS Surakarta athletes to analyze and find out more about this research.

\section{METHODS}

The study uses quantitative methods and confirmatory factor analysis design. The approach taken in this research is a quantitative approach, using the design of Confirmatory Factor Analysis (23). Factor analysis is a multivariate statistical method that tries to explain the relationship between a number of mutually independent changes between one another so that one or more sets of changes can be made that are less than the number of initial changes. Factor analysis is used to find out the dominant factors in explaining a problem. Confirmatory factor analysis or often called confirmatory factor analysis (CFA) is used to test the dimensionality of a construct (24). Factor analysis is a way to find or get a number of indicator variables that are able to maximize the correlation between indicator variables.

The population is the entire subject of research (25). The population and sample in this study were all students fostering the achievement of UKM PSHT UNS with a total of 25 students. The sample is a part or representative being studied (26). As a sample it is better to have the same characteristics as a population so that you can draw a picture of the population. The sampling technique used was purposive sampling. 
This type of research used in this research is correlational research with confirmatory factor analysis design that confirms the relationship of indicator variables with latent variables that determine the ability of the front kick pencak silat. Data collection is processed and analyzed using a computerbased application Statistics SPSS (Product Statistics and Service Solutions) Version 23 and using the Kaiser-Meyer-Olkin test and Bartlett Test.

\section{RESULTS}

The normality test in this study uses the Kolmogorov-Smirnov One-Sample Test Method with the provisions of Ho: The population is normally distributed, Ha: The population is not normally distributed. The basis of decision making is based on probability, if the probability value $>\alpha=0.05$ then Ho is accepted If the probability value $<0.05$ then Ho is rejected.

The results of the pencak silat front kick ability instrument model from the results of the analysis (EFA) can be stated as follows: 1) There are 2 factors from the extraction that have an eigen value greater than (eigen value> 1). Both factors are factors: F1, F2. F1: Covers 3 measured variables, namely X1, X2, X3 F2: Covers 2 measured variables, namely X4, X5 The model that can be formed from the results of the factor analysis after rotation with respect to variables that have a large enough loading is as follows (source of varimax rotation results): $\mathrm{F} 1=0.923 \mathrm{X} 1+0.429 \mathrm{X} 2+0.531 \mathrm{X} 3 \mathrm{~F} 2=0.912 \mathrm{X} 4+0.240 \mathrm{X} 5$ The two factors that were successfully extracted were the dimensions of the ability of the pencak silat front kick in detail, the two dimensions and measured variables that were completed and the naming of these dimensions (factors) can be seen in table 2 below:

Table 1. Naming of the factors and variables covered

\section{FACTORS AND FACTOR NAMING}

\begin{tabular}{l|l}
\hline \multicolumn{1}{c|}{ F1 } & \multicolumn{1}{c}{ F2 } \\
\hline \multicolumn{1}{c|}{ Biomotor } & \multicolumn{1}{|c}{ Psychomotor } \\
\hline $\begin{array}{l}\text { 1. Leg muscle strength } \\
\text { 2. Flexibility }\end{array}$ & 1. Balance \\
3. Power the Abdominal Muscles & 2. Agility \\
\hline
\end{tabular}

Table 2.Summary of Descriptive Analysis of Data on Biomotor and Psychomotor

\begin{tabular}{l|c|c|c|c|c}
\hline & $\mathrm{N}$ & Min & Max & Mean & Std. Deviation \\
\hline Vertical Jump & 25 & 26 & 65 & 43.20 & 11.015 \\
\hline Standing Trunk Flexion & 25 & 8 & 28 & 19.28 & 4.532 \\
\hline Abdominal muscles & 25 & 24 & 48 & 33.20 & 6.801 \\
\hline Modified Balanced Test & 25 & 6 & 10 & 8.80 & 1.354 \\
\hline T-Test & 25 & 9.83 & 12.67 & 11.3432 & .77446 \\
\hline Front Kick Ability & 25 & 6 & 26 & 14.52 & 5.277 \\
\hline Valid N (listwise) & 25 & & & & \\
\hline
\end{tabular}


The normality test in this study used the One-Sample Kolmogorov-Smirnov Test with the provisions Ho: The population is normally distributed, Ha: The population is not normally distributed. The basis for decision making is based on probability, if the probability value $>\alpha=0.05$ then Ho is accepted. If the probability value $<0.05$ then Ho is rejected.

Table 3. Summary of Normality Test Results

\begin{tabular}{l|c|c|c|c}
\hline \multicolumn{1}{c|}{ Variable } & N & $\begin{array}{c}\text { Asymp. Sig } \\
\text { (2-tailed) }\end{array}$ & Probability & Conclusion \\
\hline Power of limb muscles (X1) & 25 & 0,030 & 0,05 & $\begin{array}{c}\text { Abnormal } \\
\text { distribution data }\end{array}$ \\
\hline Flexibility (X2) & 25 & 0,200 & 0,05 & $\begin{array}{c}\text { Normally } \\
\text { Distributed Data }\end{array}$ \\
\hline Power the abdominal muscles (X3) & 25 & 0,200 & 0,05 & $\begin{array}{c}\text { Normally } \\
\text { Distributed Data }\end{array}$ \\
\hline Balance (X4) & 25 & 0,000 & 0,05 & $\begin{array}{c}\text { Abnormal } \\
\text { distribution data }\end{array}$ \\
\hline Agility (X5) & 25 & 0,200 & 0,05 & \begin{tabular}{c} 
Normally \\
Distributed Data \\
\hline Front kick ability (Y)
\end{tabular} \\
\hline
\end{tabular}

Table 4. Summary of Linearity Test Results

\begin{tabular}{l|l|c|l}
\hline Variable & Linearity & Significance & Conclusion \\
\hline X1Y & 0,417 & 0,05 & Linear Pattern \\
\hline X2Y & 0,349 & 0,05 & Linear Pattern \\
\hline X3Y & 0,786 & 0,05 & Linear Pattern \\
\hline X4Y & 0,635 & 0,05 & Linear Pattern \\
\hline X5Y & 0,628 & 0,05 & Linear Pattern \\
\hline
\end{tabular}

Hypothesis testing is basically a step to test or find the truth whether the null hypothesis (H0) proposed at a certain level of significance is rejected and the alternative hypothesis (Ha) is accepted, or vice versa, the null hypothesis (H0) is accepted and the alternative hypothesis (Ha) is rejected. To find out this, in this study, hypothesis testing was obtained by looking at the value of the calculation results of the Anti-image Matrices Correlation and the rotated component matrixa. 


\section{DISCUSSION}

Based on the hypotheses that have been proposed and the calculation of the factor analysis statistics that have been done, the results of the hypothesis testing of this study are:

1. Biomotor factor of leg muscle power, flexibility, abdominal muscle power contribute to determine the ability of the front kick pencak silat :

a. Leg muscle power contributes to determine the ability of pencak silat front kicks $85 \%$ and rotated component matrix value of 0.922 which means that leg muscle power is a member of biomotor and psychomotor determinants of pencak silat (H1 accepted) front kick ability .

b. Flexibility contributes to determining the ability of the front kick pencak silat Based on the antiimage matrices correlation value contained in the factor has a value of 0.795 or $>0.5$ with a value of communalities at 0.275 which means flexibility has a percentage of the role of the factor of $27 \%$ and a rotated component matrix value of 0.430 which means flexibility is a member of the biomotor factor and psychomotor which determines the ability of the front kick pencak silat ( $\mathrm{H} 2$ is accepted).

c. Abdominal muscle power contributes to determine the ability of the front kick pencak silat Based on the anti-image matrices correlation value found in the abdominal power factor has a value of 0.798 or $>0.5$ with a communalities value of 0.557 , which means the abdominal power has a percentage of the role of the factor of $56 \%$ and a rotated component matrix value of 0.54 which means the abdominal muscle power is a member of the biomotor factor that determines the ability of the front kick pencak silat (H3 accepted).

2. Psychomotor factors, balance and agility contribute to determining the ability of pencak silat front kicks:

a. Balance contributes to determining the ability of a pencak silat front kick Based on the anti-image matrices correlation value, there is a balance factor that has a value of 0.668 or or $>0.5$ with the value of communalities in table 4.8 of 0.833 , which means that hand eye coordination has a role percentage of the factor of $83 \%$ and a rotated component matrix value of 0.912 . which means that balance is a member of the psychomotor factors that determine front kick ability (H4 accepted).

b. Agility contributes to determining the ability of pencak silat front kicks. Based on the anti-image matrices correlation value, the agility factor has a value of 0.730 or $>0.5$ with the value of communalities in table 4.6 of 0.702 which means that it has a role percentage of the factor of $70 \%$ and a rotated component matrix value of 0.240 which means that is agility. eligible to be a member of the psychomotor factors that determine front kick ability (H5 accepted).

\section{CONCLUSION}

Based on the results of hypothesis testing about the analysis of biomotor and psychomotor factors that determine the ability of the pencak silat front kick above, the biomotor and psychomotor factors that determine the ability of the front kick of pencak silat ( $\mathrm{H} 0$ accepted) or those that have a factor component value of $\geq 0.5$ are: Biomotor and psychomotor factors that contribute to determining the ability of pencak silat front kicks 1 . Power of leg muscles with a factor component value of 0.922 . Flexibility with a factor component value of 0.433 . Power the abdominal muscles with a factor component value of 0.534 . The balance with the factor component value is 0.915 . Agility with a factor component value of 0.24 The results of the statistical analysis of biomotor and psychomotor factors that contribute to determining the ability of the front kick of pencak silat are leg muscle power (0.92), balance (0.91), abdominal muscle power (0.53), flexibility (0.42), and agility (0.24).

\section{REFERENCES}

1. Giriwijoyo Hyss, Sidik DZ. Konsep Dan Cara Penilaian Kebugaran Jasmani Menurut Sudut Pandang Ilmu Faal Olahraga. J Kepelatihan Olahraga. 2010; 
2. Putra RT, Kiyatno, Siswandari. Analisis Faktor Biomotor dan Psikomotor Dominan Penentu Kemampuan Groundstroke Forehand Tenis Lapangan. Univ Sebel Maret. 2017;

3. Kartomi M. Traditional and modern forms of pencak silat in Indonesia: The suku mamak in Riau. Musicol Aust. 2011;

4. Widiastuti. Using game approach in improving learning outcomes of pencak silat. Asian Soc Sci. 2014;

5. Ediyono S, Dzakiria H. Sustaining the Indonesian martial art (Pencak silat) and culture for good character building: A systemic analysis. Adv Sci Lett. 2016;

6. Dei A. Relationship between length of leg and strength of leg muscle to frequency of straight kicks. Int Res J Eng IT Sci Res. 2020;

7. Sunardi C. The Fighting Art of Pencak Silat and Its Music: From Southeast Asian Village to Global Movement ed. by Uwe U. Paetzold and Paul H. Mason. Asian Music. 2019;

8. Dongoran MF, Muhammad Fadlih A, Riyanto P. Psychological characteristics of martial sports Indonesian athletes based on categories art and fight. Enferm Clin. 2020;

9. Muhamad, Memet; Haqiyah, Aridhotul; Riyadi DN. Positive Self-Talk on Pencak Silat Performance. J Phys Educ Sport Heal Recreat. 2019;

10. Lestari DS, Sutapa P. The Skills Development of Pencak Silat Training Model based on Traditional Games Movement. In 2020.

11. Sartono N, Puspitaningrum R, Lubis J, Siregar NM. Profile energy national athlete of Indonesia Pencak silat. In: AIP Conference Proceedings. 2018.

12. Hajir A. The Influence Of Flexibility, Strength, And Balance On Straight Forward Kick Skilss Of Pencak Silat Athletes In Palopo City. Pascasarj UNM. 2019;

13. Trisnowiyanto B. Latihan Peningkatan Kemampuan Biomotor (Kelincahan, Kecepatan, Keseimbangan Dan Fleksibilitas) Dengan Teknik Lari (Shuttle Run, Zig-Zag, Formasi 8) Pada Pesilat. J Keterapian Fis. 2016;

14. Rahman NA. Model latihan untuk mengembangkan biomotor endurance pesilat remaja. Musamus J Phys Educ Sport. 2019;

15. Iswana B, Siswantoyo S. Model latihan keterampilan gerak pencak silat anak usia 9-12 tahun. J Keolahragaan. 2013;

16. Hoque ME. Three domains of learning - cognitive, affcetive, psychomotor. J EFL Educ Res. 2019;

17. Dlugonski D, DuBose KD, Rider P. Accelerometer-measured patterns of shared physical activity among mother-young child dyads. J Phys Act Heal. 2017;

18. Milić M, Grgantov Z, Katić R. Biomotor status and kinesiological education of girls aged 10 to 12 years--example: volleyball. Coll Antropol. 2012;

19. Čavala M, Katić R. Morphological, motor and situation-motor characteristics of elite female handball players according to playing performance and position. Coll Antropol. 2010;

20. Prasetyo FY. The physical conditions of Pencak Silat athletes. In: IOP Conference Series: Materials Science and Engineering. 2017.

21. Dimyati, Irianto Dp, Lumintuarso Ria. Exploring the Psychological Skills of Indonesian Pencak 
Silat Athletes at the 18th Asian Games. / Badanie umiejętności psychologicznych indonezyjskich zawodników Pencak Silat podczas 18 Igrzysk Azjatyckich. Ido Mov Cult J Martial Arts Anthropol. 2020;

22. Akbar M, Hardiansyah L, Septiandi B, Rusdiana A. Roundhouse Kick Cinematic Analysis - The Comparison between Skill and Unskill in Pencak Silat. In 2018.

23. Finch WH, French BF, Finch WH, French BF. Exploratory and Confirmatory Factor Analysis. In: Educational and Psychological Measurement. 2018.

24. Johnston R. Confirmatory Factor Analysis (CFA). In: Encyclopedia of Quality of Life and WellBeing Research. 2014.

25. Arikunto S. Prosedur Penelitian, Jakarta. Rineka Cipta. 2010;

26. Ariakujto. Sampel Penelitian. J Chem Inf Model. 2019; 